\title{
Sporadic Fundic Gland Polyps
}

\section{Common Gastric Polyps Arising Through Activating Mutations in the $\beta$-Catenin Gene}

\author{
Susan C. Abraham, ${ }^{\star}$ Bunsei Nobukawa, ${ }^{*}$ \\ Francis M. Giardiello, ${ }^{\dagger}$ Stanley R. Hamilton, ${ }^{\star}$ and \\ Tsung-Teh $\mathrm{Wu}^{*}$
}

testinal tract to demonstrate $\beta$-catenin mutations while lacking dysplastic morphology. (Am J Patbol 2001, 158:1005-1010)

Fundic gland polyps (FGPs) are the most common polyps of the stomach, comprising almost half of benign gastric polyps. ${ }^{1}$ FGPs are typically small (2 to $5 \mathrm{~mm}$ ) polyps located in the gastric body and fundus, and may be single or multiple. ${ }^{1-5}$ Histopathologically, FGPs are characterized by cystically dilated fundic glands lined by flattened parietal cells, chief cells, and variable numbers of mucous neck cells. The overlying surface and foveolar gastric epithelium is typically nondysplastic in morphology (Figure 1). FGPs arise in a background of otherwise normal, nonatrophic gastric mucosa. ${ }^{4-6}$

FGPs occur in both sporadic and syndromic forms. Sporadic FGPs are identified in 0.8 to $1.9 \%$ of patients undergoing upper gastrointestinal endoscopy, and are especially prevalent among middle-aged females. ${ }^{4,7,8}$ In patients with familial adenomatous polyposis (FAP), FGPs are increased in prevalence, are more frequently multiple, occur at younger ages, and show a more equal gender distribution than sporadic FGPs. ${ }^{3,7-9}$ In addition, up to $25 \%$ of FAP-associated FGPs show foveolar epithelial dysplasia. ${ }^{10-12}$ FAP-associated FGPs have been reported in 12.5 to $84 \%$ of patients. ${ }^{9,13-23}$

The pathogenesis of FGPs remains uncertain. FGPS have generally been regarded as nonneoplastic lesions, either hamartomatous or hyperplastic/functional in nature. ${ }^{4,24,25}$ However, we have recently demonstrated a high frequency of somatic, "second hit" alterations in the adenomatous polyposis coli (APC) gene on chromosome $5 q$ in FGPs associated with FAP, but not in sporadic FGPs. ${ }^{26}$ The APC gene product regulates the level of $\beta$-catenin protein, which functions both as a submembranous component in cadherin-mediated cell-cell adhesion and as a downstream transcriptional activator in the Wnt

Supported in part by an award from BioNumerik Pharmaceuticals, Inc. (to S. C. A.).

Accepted for publication November 9, 2000

Address reprint requests to Susan C. Abraham, M.D., Division of Gastrointestinal/Liver Pathology, Department of Pathology, Ross Building, Room 632, The Johns Hopkins University School of Medicine, 720 Rutland Ave., Baltimore, MD 21205-2196. E-mail: sabraham@jhmi.edu. matous (dysplastic) or neoplastic polyps. Sporadic FGPs are therefore the only lesions of the gastroin- 

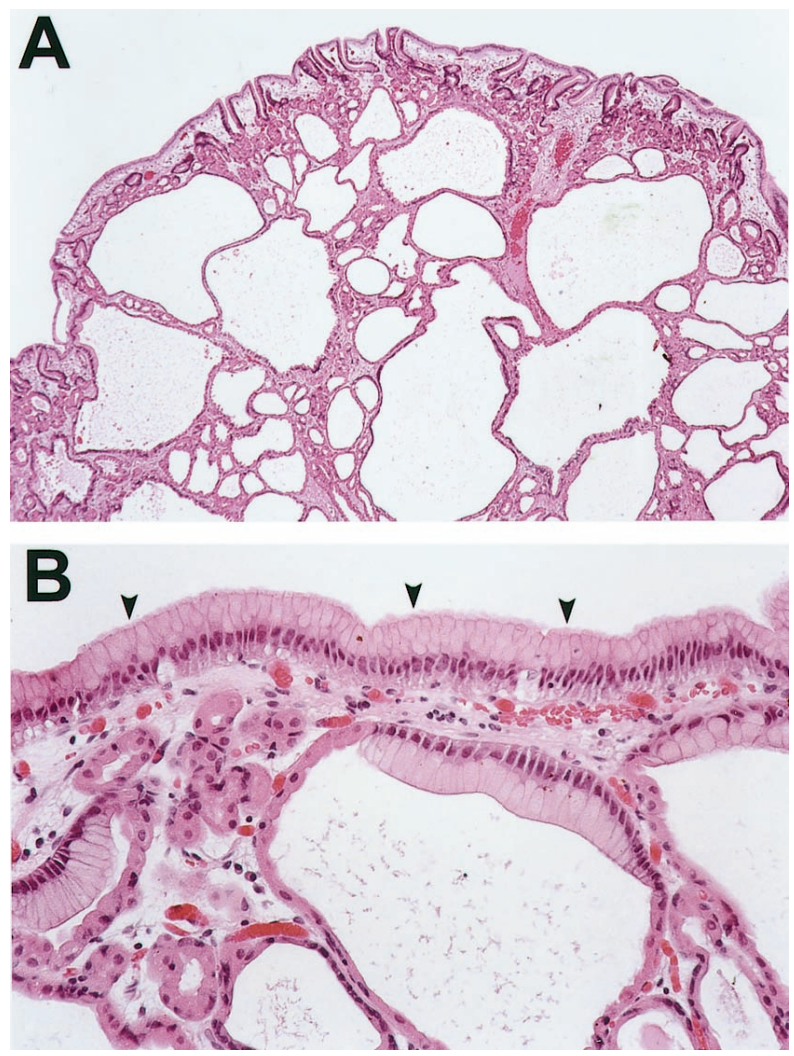

Figure 1. Histopathological appearance of FGPs. A: Polyps are composed of cystically dilated fundic glands. B: The dilated fundic glands are lined by attenuated parietal cells, chief cells, and mucous neck cells. The overlying surface/foveolar epithelium (arrowheads) is typically nondysplastic. H\&E stain; original magnifications: $\times 40(\mathbf{A}) ; \times 200(\mathbf{B})$

signaling pathway. ${ }^{27,28}$ APC tumor suppressor protein, in cooperation with glycogen synthase kinase-3 $\beta$ (GSK-3 $\beta$ ), promotes phosphorylation of serine/threonine residues encoded in exon 3 of the $\beta$-catenin gene. ${ }^{27,29,30}$ Phosphorylation is followed by ubiquitin-mediated degradation of $\beta$-catenin protein. ${ }^{31,32}$ Loss of $\beta$-catenin regulatory activity resulting in accumulation of $\beta$-catenin protein can occur via either truncating APC gene mutations or stabilizing $\beta$-catenin gene mutations at GSK-3 $\beta$ phosphorylation sites. ${ }^{30,33,34}$ A majority of colorectal adenomas and carcinomas can be demonstrated to contain either biallelic inactivation of the APC gene or activating $\beta$-catenin gene mutations. ${ }^{35,36}$

The presence of somatic APC gene alterations in FAPassociated FGPs but not in sporadic FGPs raised the possibility that $\beta$-catenin gene mutations affecting the APC/ $\beta$-catenin pathway might be involved in the pathogenesis of sporadic FGPs. We therefore analyzed for $\beta$-catenin mutations in a series of sporadic FGPs from patients without FAP and compared the findings with those of FAP-associated FGPS.

\section{Materials and Methods}

\section{Case Selection}

The study population consisted of 57 sporadic FGPs from 40 patients without FAP who underwent upper gastroin- testinal endoscopy at The Johns Hopkins Hospital between 1998 and 1999. For comparison, we included 19 FGPs from 13 patients with FAP who underwent endoscopic biopsy between 1991 and 1999. We had previously analyzed the 19 FAP-associated FGPs for somatic APC gene alterations and had been unable to detect either $5 q$ allelic loss or APC gene mutations on sequencing of polymerase chain reaction (PCR) products in the APC mutation cluster region for gastroduodenal polyps. ${ }^{26}$ Surface/foveolar epithelial dysplasia in FGPs was graded on histological examination of hematoxylin and eosin (H\&E)-stained histological sections according to previously published criteria $^{10}$ : negative for dysplasia (all 57 sporadic FGPs and seven FAP-associated FGPs), indefinite for dysplasia (two FAP-associated FGPs), and dysplastic (10 FAP-associated FGPs).

\section{Immunohistochemistry for $\beta$-Catenin}

Immunohistochemistry for $\beta$-catenin was performed on the 57 sporadic FGPs. Immunoperoxidase stain using diaminobenzidine as the chromogen was performed on the Techmate 1000 automatic staining system (BioTek Solutions, Tucson, AZ). Deparaffinized sections of formalin-fixed tissue were stained with $\beta$-catenin antibody (mouse monoclonal antibody; Becton Dickinson Transduction Laboratories, Lexington, KY) at 1:500 dilution after heat-induced antigen retrieval. ${ }^{37}$

\section{DNA Extraction}

Microdissection of slides for DNA extraction was performed from formalin-fixed, paraffin-embedded specimens. A 271/2-gauge needle tip was used for microdissection of the H\&E-stained tissue under a low-power $(\times 4)$ objective, and needles and gloves were routinely changed for each dissection. In 22 of 57 sporadic FGPs, the surface/foveolar epithelium and dilated fundic glands were microdissected and analyzed separately. In the remaining sporadic FGPs and in all 19 of the FAP-associated FGPs, only the dilated fundic glands were microdissected. Genomic DNA was extracted as described previously. ${ }^{38}$ Corresponding control DNA was extracted from nonneoplastic gastric or duodenal epithelium in 37 of 40 non-FAP patients.

\section{Mutation Analysis of the $\beta$-Catenin Gene}

Genomic DNA from each sample was amplified by PCR using the following primer pair: forward, 5'-ATGGAACCAGACAGAGGGGC-3' and reverse, 5'-GCTACTTGTTCTGAGTGAAG-3'. These amplified a 200-bp fragment of exon 3 of the $\beta$-catenin gene encompassing the region for GSK-3 $\beta$ phosphorylation. PCR reaction was performed under standard conditions in a $25-\mu$ l volume using PCR Master (Boehringer Mannheim, Mannheim, Germany) and $1 \mu \mathrm{mol} / \mathrm{L}$ of both $5^{\prime}$ and $3^{\prime}$ oligonucleotides with 40 cycles $\left(94^{\circ} \mathrm{C}\right.$ for 1 minute, $58^{\circ} \mathrm{C}$ for 1 minute, and $72^{\circ} \mathrm{C}$ for 2 minutes). PCR products were treated using shrimp alkaline phosphatase and exonuclease I (Amer- 
sham, Buckinghamshire, UK) before sequencing. Treated PCR products were sequenced directly with SequiTherm Excel II DNA sequencing kit (Epicentre, Madison, WI) using internal primers (forward, 5'-AAAGCGGCTGTTAGTCACTFF-3' and reverse, 5'GACTTGGGAGGTATCCACATCC-3'). Oligonucleotides were end-labeled with $\left(\gamma_{-}{ }^{32}\right.$ P)-ATP (New England Nuclear-DuPont, Boston, MA) using T4 polynucleotide kinase (New England Biolabs, Beverly, MA). All mutations were verified in both sense and antisense directions. Base substitutions in codons 32,33 , and the second position of codon 34 were further confirmed by Hinfl restriction endonuclease assay (Life Technologies, Inc., Rockville, MD). The 200-bp PCR product for $\beta$-catenin contains two Hinfl restriction endonuclease sites, yielding 7-bp, 55-bp, and 138-bp DNA fragments after digestion of the wildtype allele. $\beta$-catenin mutations in codons 32 and 33 yield only $62-\mathrm{bp}$ and 138 -bp fragments after digestion because of ablation of the first Hinfl site. Mutations in the second position of codon 34 yield 55-bp and 145-bp fragments because of ablation of the other Hinfl site.

\section{Statistical Analysis}

Chi-square test was used to compare frequencies of $\beta$-catenin gene mutations between sporadic FGPs and FAP-associated FGPs. A $P$ value of $<0.05$ was considered statistically significant.

\section{Results}

Fifty-two of 57 sporadic FGPs (91.2\%) contained mutations in exon 3 of the $\beta$-catenin gene. The somatic nature of the mutations was confirmed by the absence of $\beta$-catenin gene mutations in the corresponding normal tissue from these patients. In 51 sporadic FGPs, mutations were 1-bp missense mutations, predominantly in one of the serine/threonine residues at GSK-3 $\beta$ phosphorylation sites: codon 32 (five cases), codon 33 (19 cases), codon 34 (nine cases), and codon 37 (18 cases) (Figures 2 and 3). One additional FGP contained a 15-bp deletion mutation spanning codons 32 to 37 . In all cases demonstrating $\beta$-catenin gene mutations, a mixture of the wild-type and altered bands was present on sequencing, as expected, because of the dominant-positive nature of $\beta$-catenin gene alterations. Of 31 mutations that could theoretically be confirmed by Hinfl restriction endonuclease digestion, 30 cases demonstrated the expected ablation of the Hinfl recognition site (insufficient DNA was present for analysis in the remaining case) (Figure 2).

Among the 57 sporadic FGPs, we separately microdissected and analyzed both the surface/foveolar epithelium and underlying dilated fundic glands in 22 FGPs. Twentyone of 22 cases (95\%) showed concordant $\beta$-catenin mutation analysis, indicating that $\beta$-catenin mutations in FGPs are localized both to the glandular and surface epithelial compartments. In the remaining case, the glandular epithelium demonstrated a codon 33 TCT $\rightarrow$ TGT substitution that was not detected by sequencing of the surface epithelium. However, Hinfl restriction endonucle-
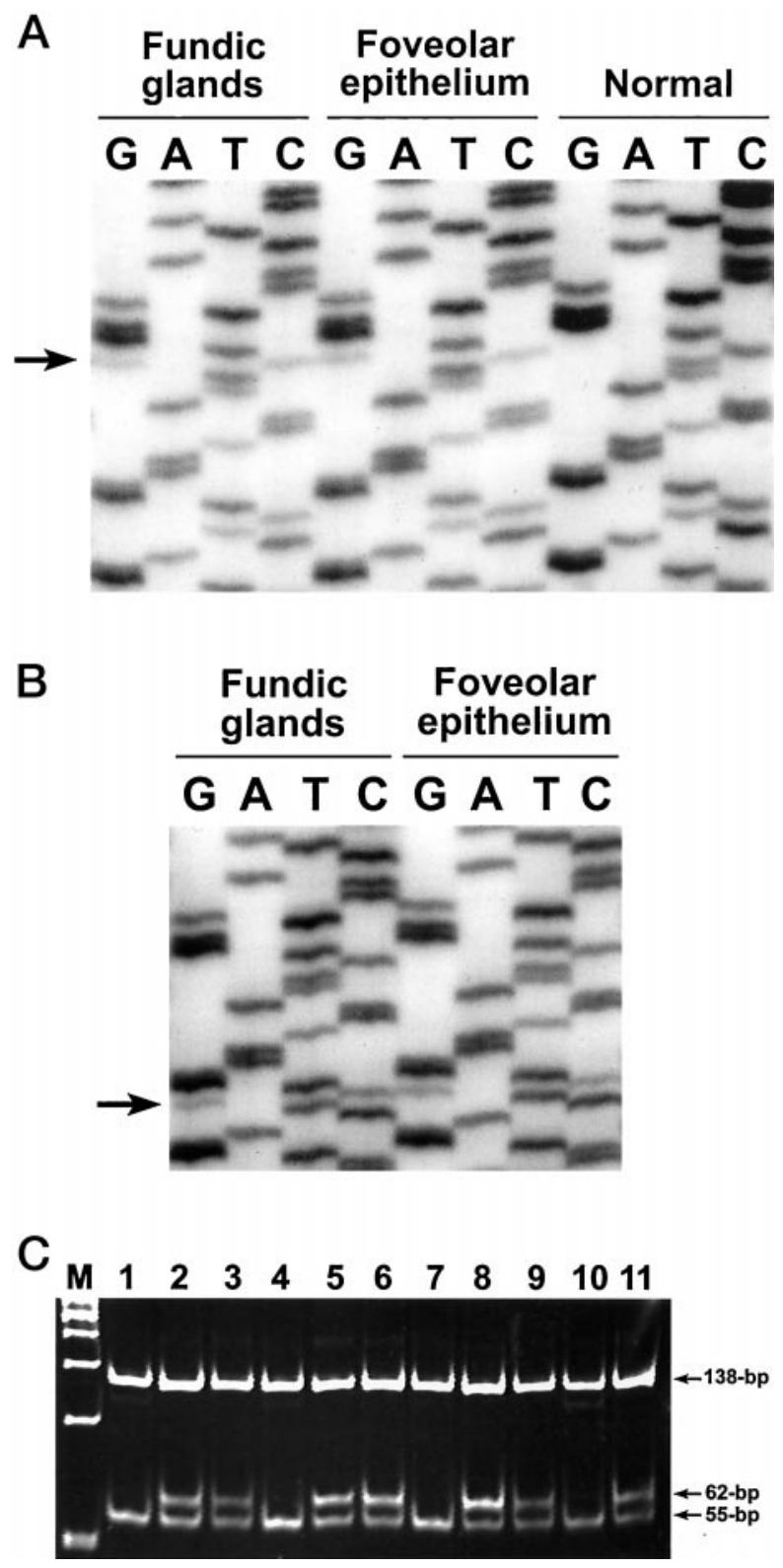

Figure 2. Representative somatic $\beta$-catenin gene mutations in sporadic FGPs. A: DNA sequencing autoradiograph of a TCT (serine) $\rightarrow$ TGT (cysteine) mutation (arrow) at codon 37, present in both the surface/foveolar epithelium and the epithelium of the dilated fundic glands from an FGP (patient 17). No $\beta$-catenin mutation is present in the corresponding normal, nonpolypoid gastric mucosa from the same patient. B: DNA sequencing autoradiograph of a TCT (serine) $\rightarrow$ TGT (cysteine) mutation (arrow) at codon 33 in both the surface/ foveolar epithelium and the epithelium of the dilated fundic glands from an FGP (patient 13). C: HinfI restriction endonuclease assay to verify the presence of a point mutation in this case and in other representative cases with codon 32 and 33 mutations. DNA samples are from sporadic FGPs from patients 11, 12, 13, and 2 (dilated fundic glands, lanes 3, 6, 9, and 11; overlying surface/foveolar epithelium, lanes $\mathbf{2}, \mathbf{5}$, and $\mathbf{8}$ ) and normal tissue from the respective patients (lanes 1, 4, 7, and 10). The normal 200-bp PCR product for $\beta$-catenin contains two HinfI restriction endonuclease sites, yielding 7-bp, 55-bp, and 138-bp DNA fragments after digestion of the wild-type allele (the 7-bp fragment is too small to be visualized on the gel). $\beta$-catenin mutations in codons 32 and 33 yield 62 -bp and 138-bp fragments after digestion because of ablation of the first HinfI site. A molecular weight marker of 50-bp ladder is in lane $\mathbf{M}$

ase analysis was positive in both compartments, suggesting that Hinfl digestion was more sensitive for the detection of mutations than was DNA sequencing. 


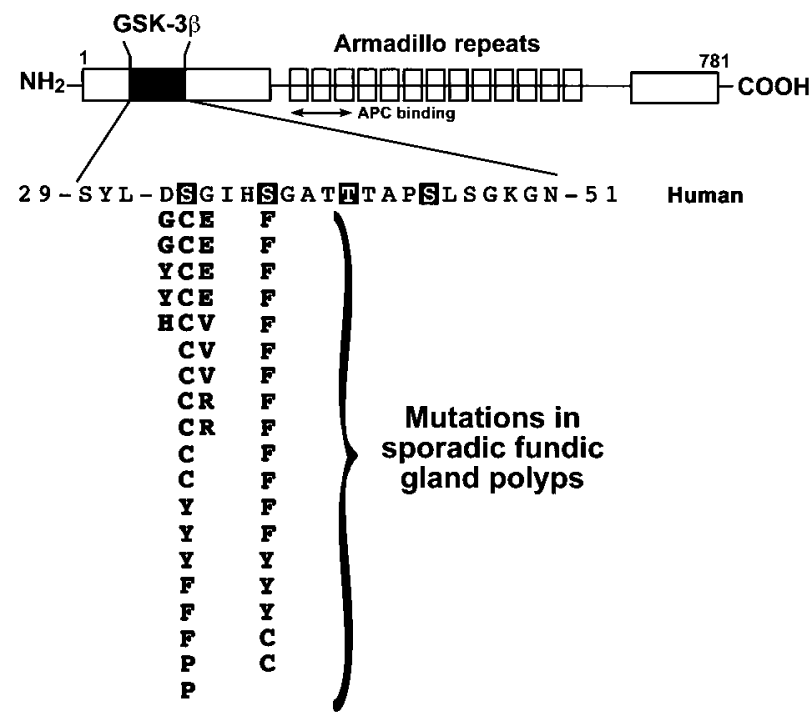

Figure 3. Summary of $\beta$-catenin mutations in sporadic FGPs. Schematic of the $\beta$-catenin gene, wild-type GSK- $3 \beta$ binding sequence in humans (with serine/ threonine phosphorylation sites in bold type), and $\beta$-catenin point mutations present in sporadic FGPs. S, serine; Y, tyrosine; L, leucine; D, aspartic acid; G, glycine; I, isoleucine; $\mathrm{H}$, histidine; A, alanine; T, threonine; $\mathrm{P}$, proline; $\mathrm{K}$, lysine; $\mathrm{N}$, asparagine. In addition to the point mutations shown in the diagram, one FGP contained a 15-bp deletion spanning codons 32 to 37.

In nine patients without FAP, multiple (two to five) FGPs were analyzed. Eight of nine patients had at least two FGPs with different $\beta$-catenin gene mutations, emphasizing the somatic and multifocal nature of the genetic alterations. A summary of the findings in these nine patients is shown in Table 1.

Immunohistochemistry did not demonstrate nuclear accumulation of $\beta$-catenin in the surface/foveolar epithelium in any of the sporadic FGPs. The dilated fundic glands showed diffuse membranous and cytoplasmic staining of the parietal cells lining the fundic glands in all polyps. However, similar staining was also present in separate fragments of nonpolypoid fundic mucosa present on the same slides (Figure 4).

In contrast to the high frequency of $\beta$-catenin gene mutations in sporadic FGPs, mutations in $\beta$-catenin were not present in any of the 19 FAP-associated FGPs, a subset of FAP-associated FGPs in which we had previously failed to detect somatic APC gene alterations $(P<$ 0.000001).

\section{Discussion}

We identified mutations in exon 3 of the $\beta$-catenin gene in $52(91 \%)$ of 57 sporadic FGPs of the stomach. These mutations were predominantly 1-bp missense mutations in codons 33 and 37 (37 cases total) leading to loss of serine or threonine sites for GSK-3 $\beta$ phosphorylation. Other exon 3 mutations in codons 32 or 34 (14 cases total) did not involve loss of a phosphorylation site but may still interfere with degradation of the $\beta$-catenin gene product. ${ }^{36}$ Only one case showed a deletion mutation, a 15-bp deletion spanning codons 32 to 37 that would lead to loss of multiple phosphorylation sites. $\beta$-catenin gene
Table 1. Somatic $\beta$-Catenin Gene Mutations from Patients with Multiple FGPs

\begin{tabular}{|c|c|c|c|}
\hline \multirow[b]{2}{*}{ Patient No. } & \multirow[b]{2}{*}{ FGP No. } & \multicolumn{2}{|c|}{$\beta$-Catenin mutation } \\
\hline & & Codon & Mutation \\
\hline \multirow[t]{2}{*}{14} & 1 & 33 & $\mathrm{TCT} \rightarrow \mathrm{TGT}$ \\
\hline & 2 & 37 & $\mathrm{TCT} \rightarrow \mathrm{TGT}$ \\
\hline \multirow[t]{4}{*}{16} & 1 & 32 & $\mathrm{GAC} \rightarrow \mathrm{CAC}$ \\
\hline & 2 & 33 & $\mathrm{TCT} \rightarrow \mathrm{TGT}$ \\
\hline & 3 & 33 & $\mathrm{TCT} \rightarrow \mathrm{TTT}$ \\
\hline & 4 & 37 & TCT $\rightarrow$ TTT \\
\hline \multirow[t]{3}{*}{17} & 1 & 34 & $\mathrm{GGA} \rightarrow \mathrm{GAA}$ \\
\hline & 2 & 37 & $\mathrm{TCT} \rightarrow \mathrm{TGT}$ \\
\hline & 3 & 37 & $\mathrm{TCT} \rightarrow \mathrm{TAT}$ \\
\hline \multirow[t]{2}{*}{18} & 1 & 34 & $\mathrm{GGA} \rightarrow \mathrm{GTA}$ \\
\hline & 2 & 37 & $\mathrm{TCT} \rightarrow \mathrm{TTT}$ \\
\hline \multirow[t]{2}{*}{21} & 1 & 33 & $\mathrm{TCT} \rightarrow \mathrm{TTT}$ \\
\hline & 2 & 37 & TCT $\rightarrow$ TTT \\
\hline \multirow[t]{2}{*}{31} & 1 & 37 & TCT $\rightarrow$ TTT \\
\hline & 2 & $32-37$ & 15-bp deletion \\
\hline \multirow[t]{4}{*}{32} & 1 & 33 & $\mathrm{TCT} \rightarrow \mathrm{TGT}$ \\
\hline & 2 & 33 & $\mathrm{TCT} \rightarrow \mathrm{TGT}$ \\
\hline & 3 & 37 & $\mathrm{TCT} \rightarrow \mathrm{TAT}$ \\
\hline & 4 & 37 & $\mathrm{TCT} \rightarrow \mathrm{TAT}$ \\
\hline \multirow[t]{5}{*}{34} & 1 & 32 & $\mathrm{GAC} \rightarrow \mathrm{GGC}$ \\
\hline & 2 & 33 & $\mathrm{TCT} \rightarrow \mathrm{TGT}$ \\
\hline & 3 & 33 & $\mathrm{TCT} \rightarrow \mathrm{TGT}$ \\
\hline & 4 & 33 & $\mathrm{TCT} \rightarrow \mathrm{CCT}$ \\
\hline & 5 & 34 & GGA $\rightarrow$ GTA \\
\hline \multirow[t]{2}{*}{35} & 1 & 37 & $\mathrm{TCT} \rightarrow \mathrm{TTT}$ \\
\hline & 2 & 37 & $\mathrm{TCT} \rightarrow \mathrm{TTT}$ \\
\hline
\end{tabular}

alterations have now been reported in a wide variety of human tumors at low to high frequencies, including, among others, sporadic medulloblastomas (4.3\%), prostate carcinomas (5\%), endometrial carcinomas (13.2\%), childhood hepatoblastomas (48\%), anaplastic thyroid carcinoma $(61 \%)$, and pilomatrixomas $(75 \%) .{ }^{39-44}$ Our rate of $91 \%$ of $\beta$-catenin gene mutations in sporadic FGPs of the stomach is the highest rate of $\beta$-catenin alterations in tumors reported to date.

The high frequency of $\beta$-catenin mutations in this series of sporadic FGPs indicates that these lesions arise through activating mutations of the $\beta$-catenin gene. In contrast, somatic APC gene alterations are common but $\beta$-catenin mutations are absent in FAP-associated FGPS, suggesting that both sporadic and FAP-associated FGPs arise through different routes of an altered $A P C / \beta$-catenin/Tcf pathway. ${ }^{26}$ Despite previous conjectures that FGPs, the most commonly identified polyps of the stomach, represent hamartomatous or hyperplastic polyps, our results provide evidence that FGPs are clonal lesions and arise through genetic alterations similar to those associated with some adenomatous polyps of the gastrointestinal tract. 4,24,25,35,36

Among gastrointestinal tract lesions, activating missense or deletion mutations in exon 3 of $\beta$-catenin have been identified in $26.9 \%$ of intestinal-type gastric cancers and in a subset of colorectal adenomas and carcinomas lacking deletions in the APC gene. ${ }^{45-47}$ Of note, $\beta$-catenin mutations have been found to be significantly more frequent in small colorectal adenomas as compared to large adenomas and invasive adenocarcinomas, suggesting that $\beta$-catenin gene mutations are not equivalent 


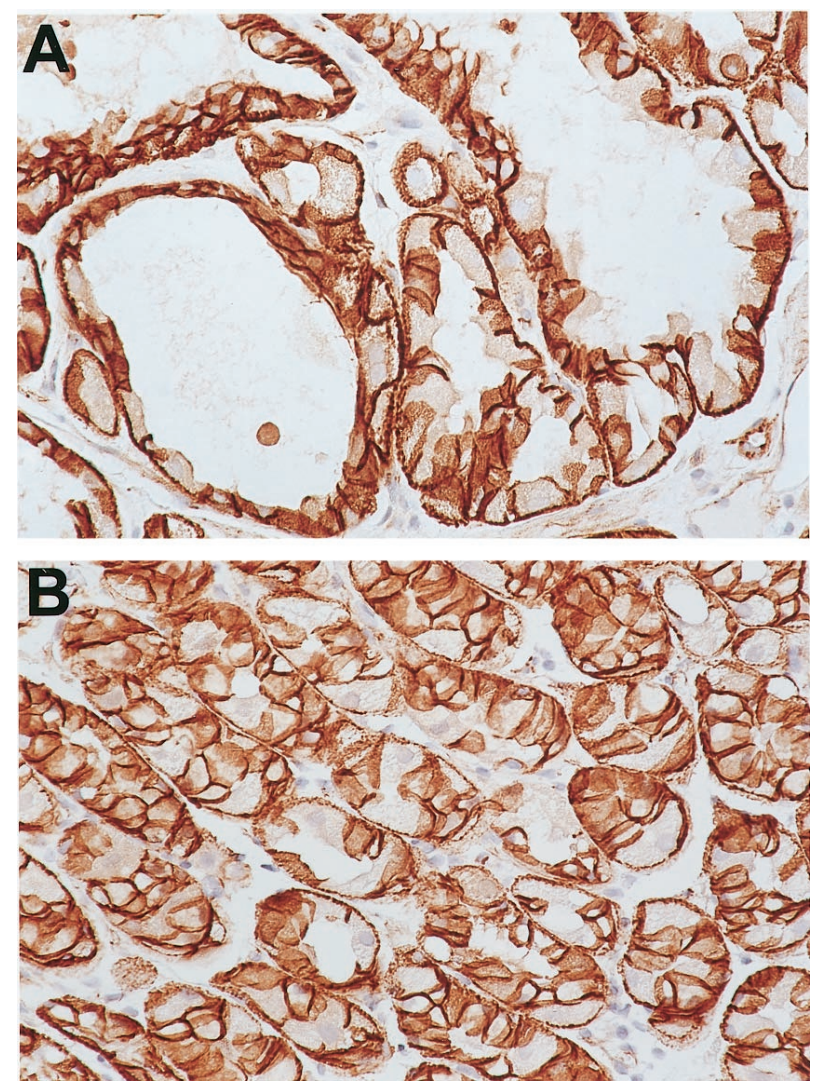

Figure 4. Immunohistochemical staining for $\beta$-catenin in sporadic FGPs. A Membranous and cytoplasmic staining for $\beta$-catenin are present in the epithelial cells lining the dilated fundic glands of an FGP, but nuclear accumulation of $\beta$-catenin is not seen. B: The same pattern of $\beta$-catenin staining is seen in the nonpolypoid fundic mucosa from the same patient.

to APC gene mutations in their oncogenic potential. ${ }^{47}$ Our finding of a high rate of $\beta$-catenin mutations in sporadic FGPs, in contrast to FAP-associated FGPs that primarily arise in association with second-hit APC alterations, ${ }^{26}$ supports this hypothesis: FAP-associated FGPs are significantly more likely to show epithelial dysplasia than are sporadic FGPs, in which epithelial dysplasia is uncommon. ${ }^{10}$ Furthermore, rare reports of invasive carcinoma arising in association with FGPs have only involved patients with FAP. ${ }^{11,48,49}$

Our results also demonstrate that $\beta$-catenin mutations in FGPs are localized both to the surface/foveolar epithelial cells and to the epithelial cells lining the dilated fundic glands, an expected finding because both compartments are known to derive from the foveolar neck region. We were unable to demonstrate nuclear accumulation of $\beta$-catenin protein by immunohistochemistry in either the surface/foveolar epithelial compartment or in the glandular compartment of these FGPs. The reason for the lack of immunohistochemical localization of $\beta$-catenin to the nucleus in unclear. However, in a study of the intracellular localization of $\beta$-catenin protein in colonic neoplasms, Kobayashi and colleagues ${ }^{50}$ found nuclear immunostaining for $\beta$-catenin in only some intramucosal and invasive adenocarcinomas but in none of the colonic adenomas, suggesting that nuclear translocation of $\beta$-catenin is seen in invasive neoplasms rather than adenomas, regardless of APC mutation status. Similarly, Anna and colleagues ${ }^{51}$ found nuclear immunostaining for $\beta$-catenin in most hepatoblastomas with $\beta$-catenin gene mutations in rats, but in none of the hepatocellular adenomas and hepatocellular carcinomas that contained $\beta$-catenin gene mutations, suggesting that translocation of $\beta$-catenin protein from the cell membrane to the nucleus is involved in tumor progression.

The etiology of the characteristic morphology of FGPs remains unclear. In contrast to adenomatous (and by definition dysplastic) gastrointestinal polyps bearing mutations of the APC or $\beta$-catenin genes, FGPs are most commonly nondysplastic in morphology. Although epithelial hyperproliferation in FGPs has been demonstrated based on higher proliferating cell nuclear antigen-labeling index in FGPs than in normal fundic mucosa, ${ }^{52}$ FGPs are now the first gastrointestinal lesion to arise in association with somatic alterations of the $\mathrm{APC} / \beta$-catenin pathway while typically displaying a nondysplastic morphology. Indeed, neoplastic progression has never been reported in sporadic FGPs. Whether this is because of an intrinsically weaker oncogenic potential of $\beta$-catenin than APC gene mutations, or to a reduced exposure of the gastric mucosa to carcinogenic stimuli as compared to that of colorectal mucosa, remains to be elucidated.

\section{Acknowledgments}

We thank Drs. Michael Goggins and James R. Eshelman for their helpful comments and critical reading of this manuscript.

\section{References}

1. Stolte M, Sticht T, Eidt S, Ebert D, Finkenzeller G: Frequency, location, and age and sex distribution of various types of gastric polyp. Endoscopy 1994, 26:659-665

2. Tatsuta M, Okuda S, Tamura H, Taniguchi H: Gastric hamartomatous polyps in the absence of familial polyposis coli. Cancer 1980, 45: 818-823

3. Odze RD, Marcial MA, Antonioli D: Gastric fundic gland polyps: a morphologic study including mucin histochemistry, stereometry, and MIB-1 immunohistochemistry. Hum Pathol 1996, 27:896-903

4. Sipponen P, Laxen F, Seppala K: Cystic 'hamartomatous' gastric polyps: a disorder of oxyntic glands. Histopathology 1983, 7:729-737

5. Lee RG, Burt RW: The histopathology of fundic gland polyps of the stomach. Am J Clin Pathol 1986, 86:498-503

6. Haruma K, Sumii K, Yoshihara M, Watanabe C, Kajiyama G: Gastric mucosa in female patients with fundic glandular polyps. J Clin Gastroenterol 1991, 13:565-569

7. Marcial MA, Villafana M, Hernandez-Denton J, Colon-Pagan JR: Fundic gland polyps: prevalence and clinicopathologic features. Am J Gastroenterol 1993, 88:1711-1713

8. Kinoshita Y, Tojo M, Yano T, Kitajima N, Itoh T, Nishiyama K, Inatome $\mathrm{T}$, Fukuzaki $\mathrm{H}$, Watanabe $\mathrm{M}$, Chiba $\mathrm{T}$ : Incidence of fundic gland polyps in patients without familial adenomatous polyposis. Gastrointest Endosc 1993, 39:161-163

9. lida M, Yao $T$, Itoh $H$, Watanabe $H$, Kohrogi N, Shigelmatsu A Iwashita A, Fujishima M: Natural history of fundic gland polyposis in patients with familial adenomatosis coli/Gardner's syndrome. Gastroenterology 1985, 89:1021-1025

10. Wu TT, Kornacki S, Rashid A, Yardley JH, Hamilton SR: Dysplasia and dysregulation of proliferation in foveolar and surface epithelia of fundic gland polyps from patients with familial adenomatous polyposis. Am J Surg Pathol 1998, 22:293-298 
11. Zwick A, Munir M, Ryan CK, Gian J, Burt RW, Leppert M, Spiro L, Chey WY: Gastric adenocarcinoma and dysplasia in fundic gland polyps of a patient with attenuated adenomatous polyposis coli. Gastroenterology 1997, 113:659-663

12. Bertoni G, Sassatelli R, Nigrisoli E, Pennazio M, Tansini P, Arrigoni A, Rossini FP, Ponz de Leon M, Bedogni G: Dysplastic changes in gastric fundic gland polyps of patients with familial adenomatous polyposis. Ital J Gastroenterol Hepatol 1999, 31:192-197

13. Watanabe H, Enjoji M, Yao T, Ohsato K: Gastric lesions in familial adenomatous coli. Hum Pathol 1978, 9:269-283

14. Spigelman AD, Williams CB, Talbot IC, Domizio P, Phillips RKS: Upper gastrointestinal cancer in patients with familial adenomatous polyposis. Lancet 1989, 2:783-785

15. Church JM, McGannon E, Hull-Boiner S, Sivak MV, Van Stolk R, Jagelman DG, Fazio VW, Oakley JR, Lavery IC, Milsom JW: Gastroduodenal polyps in patients with familial adenomatous polyposis. Dis Colon Rectum 1992, 35:1170-1173

16. Tonelli F, Nardi F, Bechi P, Taddei G, Gozzo P, Romagnoli P: Extracolonic polyps in familial polyposis coli and Gardner's syndrome. Dis Colon Rectum 1985, 28:664-668

17. Burt RW, Berenson MM, Lee RG, Tolman KG, Freston JW, Gardner EJ: Upper gastrointestinal polyps in Gardner's syndrome. Gastroenterology 1984, 86:295-301

18. Domizio P, Talbot IC, Spigelman AD, Williams CB, Phillips RKS: Upper gastrointestinal pathology in familial adenomatous polyposis: results from a prospective study of 102 patients. J Clin Pathol 1990, 43:738-743

19. Bulow S, Lauritsen KB, Johansensen A, Svendsen LB, Sondergaard JO: Gastroduodenal polyps in familial polyposis coli. Dis Colon Rectum 1985, 28:90-93

20. Sarre RG, Frost AG, Jagelman DG, Petras RE, Sivak MV, McGannon $\mathrm{E}:$ Gastric and duodenal polyps in familial adenomatous polyposis: a prospective study of the nature and prevalence of upper gastrointestinal polyps. Gut 1987, 28:306-314

21. Ranzi T, Castagnone D, Velio P, Bianchi P, Polli EE: Gastric and duodenal polyps in familial polyposis coli. Gut 1981, 22:363-367

22. Jarvinen HJ, Sipponen P: Gastroduodenal polyps in familial adenomatous and juvenile polyposis. Endoscopy 1986, 18:230-234

23. Jarvinen $H$, Nyberg $M$, Peltokallio P: Upper gastrointestinal tract polyps in familial adenomatosis coli. Gut 1983, 24:333-339

24. lida M, Yao T, Watanabe H, Itoh H, Iwashita A: Fundic gland polyposis in patients without familial adenomatosis coli: its incidence and clinical features. Gastroenterology 1984, 86:1437-1442

25. Odze R: Gastric fundic gland polyps: are they preneoplastic lesions? [letter]. Gastroenterology 1998, 114:422-423

26. Abraham SC, Nobukawa B, Giardiello FM, Hamilton SR, Wu TT: Fundic gland polyps in familial adenomatous polyposis: neoplasms with frequent somatic APC gene alterations. Am J Pathol 2000, 157: 747-754

27. Barth Al, Nathke IS, Nelson WJ: Cadherins, catenins, and APC protein: interplay between cytoskeletal complexes and signaling pathways. Curr Opin Cell Biol 1997, 9:683-690

28. Behrens J, von Kries JP, Kuhl M, Bruhn L, Wedlich D, Grosschedl R, Birchmeier W: Functional interaction of $\beta$-catenin with the transcriptional factor LEF-1. Nature 1996, 382:638-642

29. Rubinfeld B, Albert I, Porfiri E, Fiol C, Munemitsu S, Polakis P: Binding of GSK3 $\beta$ to the APC- $\beta$-catenin complex and regulation of complex assembly. Science 1996, 272:1023-1026

30. Munemitsu S, Albert I, Souza B, Rubinfeld B, Polakis P: Regulation of intracellular $\beta$-catenin levels by the adenomatous polyposis coli (APC) tumor-suppressor protein. Proc Natl Acad Sci USA 1995, 92 : 3046-3050

31. Aberle H, Bauer A, Stappert J, Kispert A, Kemler R: $\beta$-Catenin is a target for the ubiquitin-proteasome pathway. EMBO J 1997, 16:37973804

32. Orford K, Crockett C, Jensen JP, Weissman AM, Byers SW: Serine phosphorylation-regulated ubiquitination and degradation of $\beta$-catenin. J Biol Chem 1997, 272:24735-24738
33. Morin PJ, Sparks AB, Korinek V, Barker N, Clevers H, Vogelstein B, Kinzler KW: Activation of $\beta$-catenin-Tcf signaling in colon cancers by mutations in $\beta$-catenin or APC. Science 1997, 275:1787-1790

34. Korinek V, Barker N, Morin PJ, van Wichen D, de Weger R, Kinzler W, Vogelstein $\mathrm{B}$, Clevers $\mathrm{H}$ : Constitutive transcriptional activation by a $\beta$-catenin-Tcf complex in APC $^{-1-}$ colon cancer. Science 1997, 275: $1784-1787$

35. Kinzler KW, Vogelstein B: Lesions from hereditary colorectal cancer. Cell 1996, 87:159-170

36. Sparks AB, Morin PJ, Vogelstein B, Kinzler KW: Mutational analysis of the APC/ $\beta$-catenin/Tcf pathway in colorectal cancer. Cancer Res 1998, 58:1130-1134

37. Bankfalvi A, Navabi H, Bier B, Bocker W, Jasani B, Schmid KW: Wet autoclave pretreatment for antigen retrieval in diagnostic immunohistochemistry. J Pathol 1994, 174:223-228

38. Moskaluk CA, Kern SE: Microdissection and polymerase chain reaction amplification of genomic DNA from histological tissue sections. Am J Pathol 1997, 150:1547-1552

39. Zurawel RH, Chiappa SA, Allen C, Raffel C: Sporadic medulloblastomas contain oncogenic $\beta$-catenin mutations. Cancer Res 1998, 58: 896-899

40. Voeller HJ, Truica Cl, Gelmann EP: $\beta$-Catenin mutations in human prostate cancer. Cancer Res 1998, 58:2520-2523

41. Fukuchi T, Sakamoto M, Tsuda H, Maruyama K, Nozawa S, Hirohashi S: $\beta$-Catenin mutation in carcinoma of the uterine endometrium. Cancer Res 1998, 58:3526-3528

42. Koch A, Denkhaus D, Albrecht S, Leuschner I, von Schweinitz D, Pietsch T: Childhood hepatoblastomas frequently carry a mutated degradation targeting box of the $\beta$-catenin gene. Cancer Res 1999 , 59:269-273

43. Garcia-Rostan G, Tallini G, Herrero A, D'Aquila TG, Carcangiu ML, Rimm DL: Frequent mutation and nuclear localization of $\beta$-catenin in anaplastic thyroid carcinoma. Cancer Res 1999, 59:1811-1815

44. Chan EF, Gat U, McNiff JM, Fuchs E: A common human skin tumour is caused by activating mutations in $\beta$-catenin [letter]. Nat Genet 1999, 21:410-413

45. Park WS, Oh RR, Park JY, Lee SH, Shin MS, Kim YS, Kim SY, Lee HK, Kim PJ, Oh ST, Yoo NJ, Lee JY: Frequent somatic mutations of the $\beta$-catenin gene in intestinal-type gastric cancer. Cancer Res 1999 , 59:4257-4260

46. Iwao K, Nakamori S, Kameyama M, Imaoka S, Kinoshita M, Fukui T, Ishiguro S, Nakamura Y, Miyoshi Y: Activation of the $\beta$-catenin gene by interstitial deletions involving exon 3 in primary colorectal carcinomas without adenomatous polyposis coli mutations. Cancer Res 1998, 58:1021-1026

47. Samowitz WS, Powers MD, Spirio LN, Nollet F, van Roy F, Slattery ML: $\beta$-Catenin mutations are more frequent in small colorectal adenomas than in larger adenomas and invasive carcinomas. Cancer Res 1999, 59:1442-1444

48. Coffey RJ, Knight CD, Van Heerden JA, Weiland LH: Gastric adenocarcinoma complicating Gardner's syndrome in a North American woman. Gastroenterology 1985, 88:1263-1266

49. Hofgartner WT, Thorp M, Ramus MW, Delorefice G, Chey WY, Ryan CK, Takahashi GW, Lobitz JR: Gastric adenocarcinoma associated with fundic gland polyps in a patient with attenuated familial adenomatous polyposis. Am J Gastroenterol 1999, 94:2275-2281

50. Kobayashi M, Honma T, Masuda Y, Suzuki Y, Narisawa R, Ajioka Y, Asakura $\mathrm{H}$ : Nuclear translocation of $\beta$-catenin in colorectal cancer. Br J Cancer 2000, 82:1689-1693

51. Anna CH, Sills RC, Foley JF, Stockton PS, Ton TV, Devereux TR: $\beta$-Catenin mutations and protein accumulation in all hepatoblastomas examined from B6C3F1 mice treated with anthraquinone or oxazepam. Cancer Res 2000, 60:2864-2868

52. Declich P, Isimbaldi G, Sironi M, Galli C, Ferrara A, Caruso S, Baldacci MP, Stioui S, Privitera O, Boccazzi G, Frederici S: Sporadic fundic gland polyps: an immunohistochemical study of their antigenic profile. Pathol Res Pract 1996, 192:808-815 